\title{
Heartwood of Secang (Caesalpinia sappan L.) Ethanolic Extract Show Selective Cytotoxic Activities on T47D and Widr Cells But not on Hela Cells
}

\author{
Erlina Rivanti, Bani Adlina, Ika Nurzijah, Cyndwika Ayu, Adam Hermawan* \\ Cancer Chemoprevention Research Center, Faculty of Pharmacy, Universitas Gadjah Mada
}

\begin{abstract}
The present study investigate the selectivity of heartwood of secang ethanolic extract (SEE) on T47D breast cancer cells, WiDr colon cancer cells, and HeLa cervical cancer cells, compared to Vero normal epithelial cells. The cytotoxic effect was evaluated by using MTT assay with 24 -hour treatment to get $I C_{50}$ values. Selectivity was evaluated by using selectivity index (SI). SEE had a potent cytotoxic activity on T47D and WiDr cancer cells $\left(\mathrm{IC}_{50}<100\right.$ $\mu \mathrm{g} / \mathrm{mL})$. IC 50 value of HeLa cancer cells was observed on moderate cytotoxic $\left(100<1 C_{50}<1000\right.$ $\mu \mathrm{g} / \mathrm{mL}$ ). SEE demonstrated more selective to T47D and WiDr than Vero cells $(\mathrm{SI}>3)$, while in HeLa cells is not selective $(\mathrm{Sl}<3)$. This result indicating its potential of Caesalpinia sappan as a chemopreventive agent in cancer therapy.
\end{abstract}

Keywords: Cancer, selectivity, Secang, T47D, WiDr, HeLa, Vero

\section{INTRODUCTION}

Currently, a chemopreventive agent based on natural materials has been developed. It is triggered by the fact that the treatment of cancer using chemotherapeutic agents tends to cause resistance of cancer cell, resulting the majority of cancer treatment failure (Nobili, et al., 2009). In addition, in clinical application, some classical chemotherapeutics such as doxorubicin and 5-fluorouracil showed side effects such as cardiotoxicity and myelosuppression (Bowles, et al., 2012, Santos, et al., 2010). This is due to the lack of selectivity of the chemotherapeutics against cancer cells, thus causing disruption of homeostasis in the body.

One of the potential natural products as a chemopreventive agent is secang (Caesalpinia sappan L.). Heartwood of secang and its active compound, brazilin and brazilein, proved has cytotoxic effect and induce apoptosis on cancer cells. Study on antioxidant compound from $C$. sappan succeed to isolate 1',4'-dihydrospiro[benzofuran-3(2H),3'-[3H-2] benzopyran]$1^{\prime}, 6^{\prime}, 6^{\prime}, 7^{\prime}$-tetrol and 3-[[4,5-dihydroxy2(hydroxymethyl)phenyl]-methyl]-2,3-dihydro3,6-benzofurandiol (Safitri, et al., 2003). Park, et al. (2002) and Wicaksono, et al. (2008) reported that secang has cytotoxic effects on
Hep G2 and Hep 3B cancer cells. Extract of C.sappan heartwood performed anticancer activity on HNSCC4 and HNSCC31 head and neck cancer cells (Kim, et al., 2005). Ethanolic extract of $C$. sappan also showed potent radical scavenging activity of reactive oxygen species (ROS) and reactive nitrogen species (RNS) (Lee, et al., 2010).

Methanolic extract of $C$. sappan exhibited cytotoxicity $\left(\mathrm{IC}_{50}<20 \mu \mathrm{g} / \mathrm{mL}\right)$ against HepG2 liver, MCF-7 and MDA-MB-231 breast, and A549 lung cancer cell lines (Lai, et al., 2011). Yen, et al. (2010) reported that brazilein isolated from secang showed potent cytotoxic effects on Hep G2 and Hep 3b liver cancer cells, MDA-MB-231 and MCF-7 breast cancer cells, and A549 lung cancer cells. Based on those data the potency of secang as chemopreventive agent need to be explored in different cell lines.

This present study was performed with the aim of determining of cytotoxicity of heartwood of secang ethanolic extract (SEE) on T47D breast cancer cells, WiDr colon cancer cells, and HeLa cervical cancer cells and its selectivity compared to Vero normal cells.

\footnotetext{
*Corresponding author e-mail: adam_apt@ugm.ac.id
} 
The scientific data regarding the activity of SEE as a selective agent could be the basis of the use of natural products as a chemopreventive agent in cancer therapy.

\section{MATERIALS AND METHODS}

\section{Plants Material}

Heartwoods of secang were collected from Wonosari, Yogyakarta, Indonesia. Plants were identified at Laboratory of Plants Taxonomy, Faculty of Biology, Universitas Gadjah Mada, Yogyakarta. The extract was prepared by maceration methods using $70 \%$ ethanol, then the filtrate was concentrated by vacuum rotary evaporator.

\section{Cell Culture}

In the study, T47D cells, WiDr cells and HeLa cells were obtained from Prof. Masashi Kawaichi (Nara Institute of Science and Technology, NAIST, Japan), while Vero cells were obtained from Cancer Chemoprevention Research Center, Faculty of Pharmacy, UGM. Cells were cultured at $37^{\circ} \mathrm{C}$ in a humidified incubator, $5 \% \mathrm{CO}_{2}$, in suitable medium for each cells (DMEM (Gibco) for T47D and HeLa cells, RPMI 1940 (Gibco) for WiDr cells, and M199 (Gibco) for Vero cells) supplemented with $10 \%$ Fetal Bovine Serum (FBS) (Gibco), 10,000 units/ml penicillin-10,000 $\mu \mathrm{g} / \mathrm{ml}$ streptomycin (Gibco).

\section{Cytotoxicity Assay}

Cytotoxicity of SEE on T47D, WiDr, HeLa, and Vero cells were determined using MTT assay (Mosmann, 1983). Cells were distributed into 96-well plate with the density of $1 \times 10^{4}$ cells/well, then incubated in $37^{\circ} \mathrm{C}$ incubator supplemented with $5 \% \quad \mathrm{CO}_{2}$ for 24 hours. SEE was diluted in culture medium using dimethyl sulfoxide (DMSO) as co-solvent with concentration not more than $0.5 \% \mathrm{v} / \mathrm{v}$. After 24 hours incubation, the culture medium was removed, followed by washing with phosphate buffered saline (PBS). Then, 0.5 $\mathrm{mg} / \mathrm{ml}$ of MTT (3-[4,5-dimethyl thiazole-2-yl(2,5- diphenyltetrazoliumbromide)]) in PBS was added, followed by 4 hours incubation in $37^{\circ} \mathrm{C}$ with $5 \% \mathrm{CO}_{2}$. After that $10 \% \mathrm{v} / \mathrm{SDS}$ in $\mathrm{HCl}$ $0.1 \mathrm{~N}$ as stopper reagent was then added. The plate was then kept with protection from light overnight, continued with absorbance determination $(\lambda 595 \mathrm{~nm})$ using ELISA reader (Bio-Rad).

\section{Data Analysis}

The cell viability was calculated based on the formula as follow:

$\%$ of viable cells $=$

[abs. of treated cells - abs. of control medium] x100\%.

[abs. of control cells - abs. of control medium]

The selectivity of SEE on each cancer cell lines was evaluated using SI (Selectivity Index) value based on formula as follow (Prayong, et al., 2008):

$\mathrm{SI}=\frac{\mathrm{IC}_{50} \text { on Vero cells }}{\mathrm{IC}_{50} \text { on cancer cells }}$

SEE is selective if SI value >3, but not selective if $\mathrm{SI}<3$.

\section{Statistical analysis}

All data are expressed as mean and standard deviation (SD) $(n=3)$. Statistically significant difference was determined by analysis of variance (ANOVA) followed by post-hoc comparisons using Tuckey's significant difference test. Statistical significance was considered at $p<0.05$ (SPSS 17.0).

\section{RESULTS}

The cytotoxic assay was performed to determine the inhibition of SEE on the growth of T47D breast cancer cells, WiDr colon cancer cells, HeLa cervical cancer cells, and Vero normal epithelial cells. Cell viability was examined using MTT assay after 24 hours incubation. Treatment of SEE decreased cell viability of T47D, WiDr, HeLa, and Vero in dose-dependent manner (Fig. 1). Cells morphology was also observed (Fig. 2), comparing the control cells to treated cells. Treatment of SEE altered the morphology of T47D, WiDr, HeLa and Vero cells. 


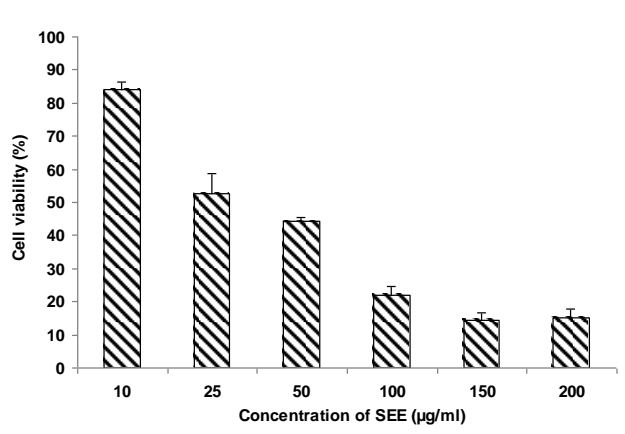

A
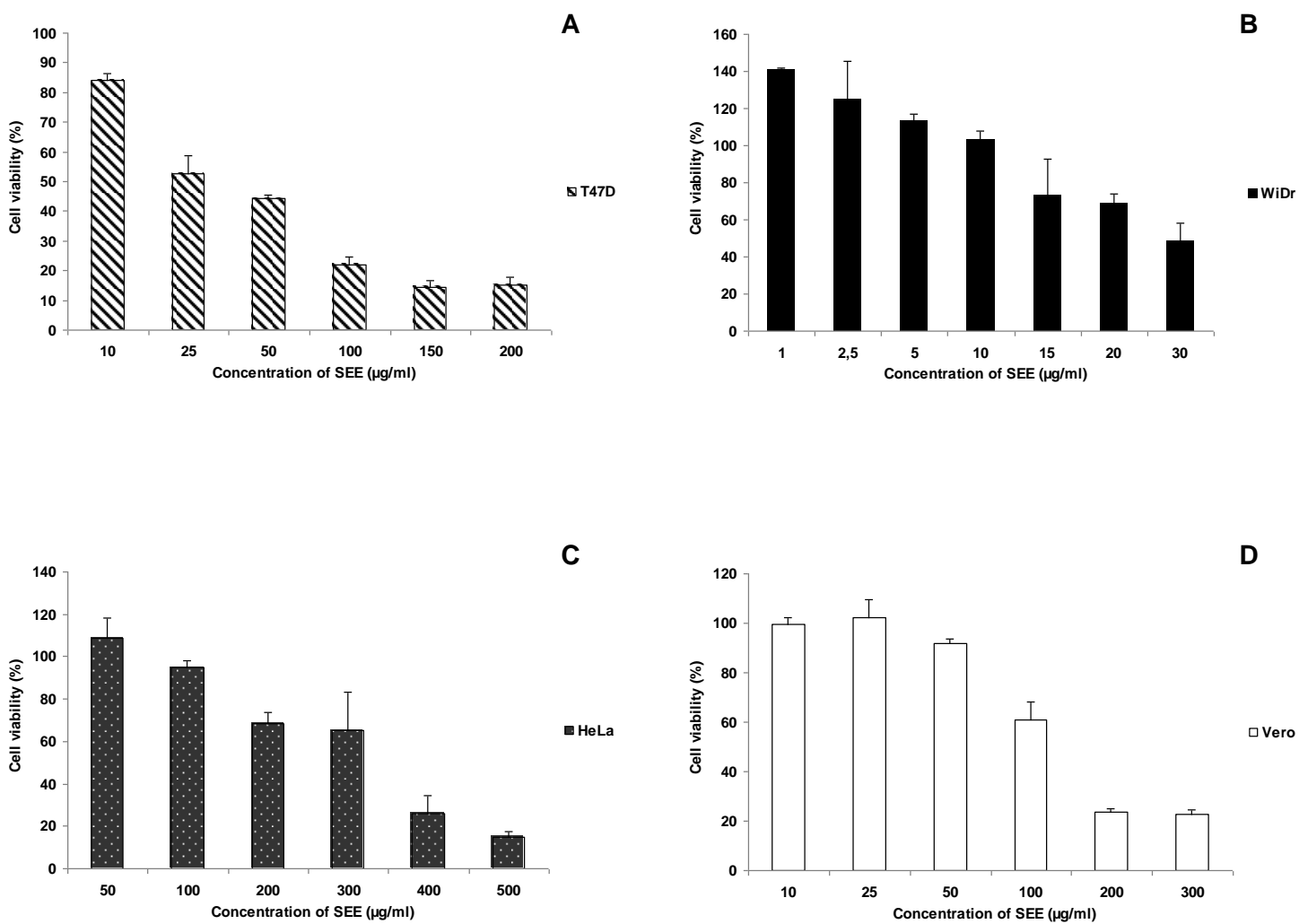

C

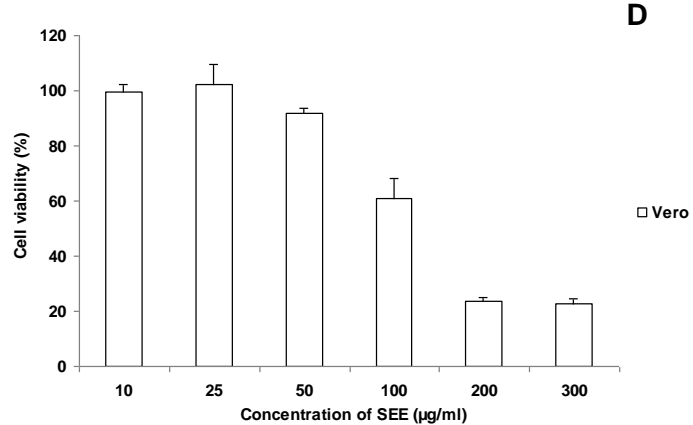

Figure I. Effects of SEE on cell growth. (a) T47D cancer cells; (b) WiDr cancer cells; (c) HeLa cancer cells; (d) Vero normal cells. SEE showed dose-dependent effect on cells growth. The assay was performed by incubating $5 \times 10^{3}$ cells/well with a serial concentration of SEE. After 24 hours, MTT reagent was added to evaluate cell viability as described in methods. Cell viability profile is shown as average \pm standard of deviation (SD) of 3 experiment. 


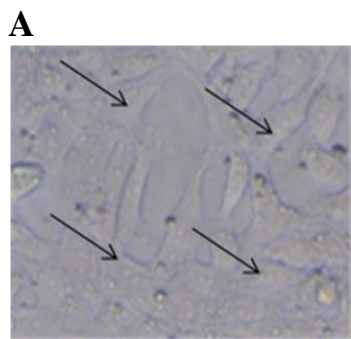

Control

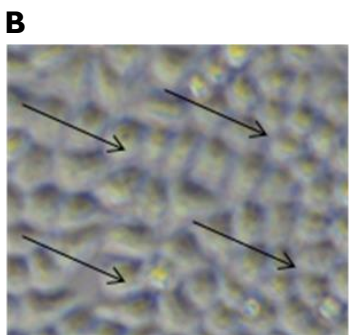

Control

c

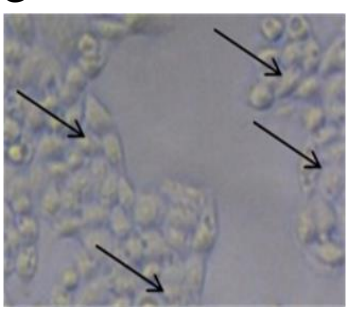

Control

D

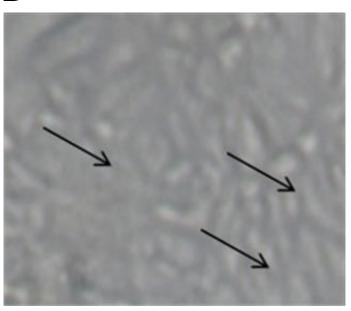

Control

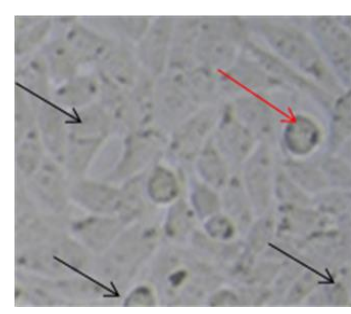

$10 \mu \mathrm{L}$

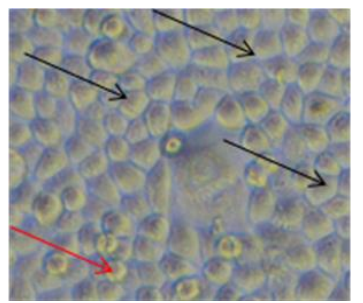

$1 \mu \mathrm{L}$

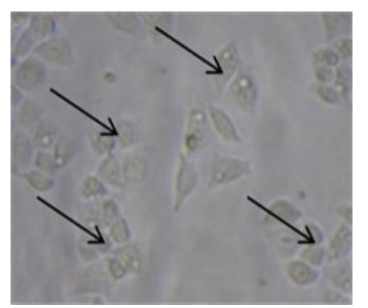

25

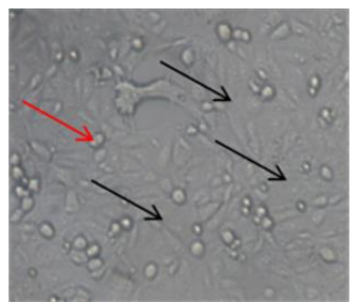

$10 \mu \mathrm{L}$

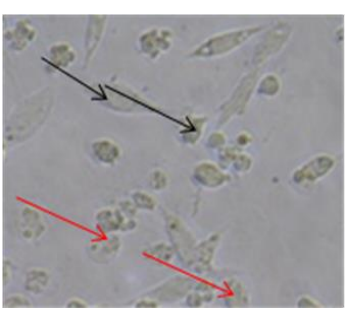

$50 \mu \mathrm{L}$

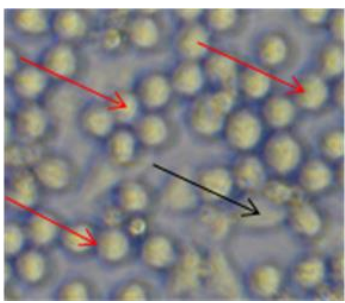

$15 \mu \mathrm{L}$

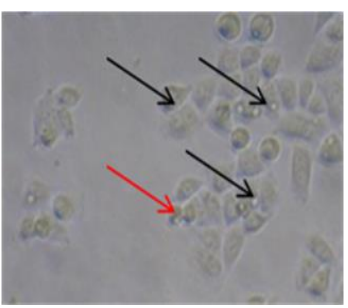

$100 \mu \mathrm{L}$

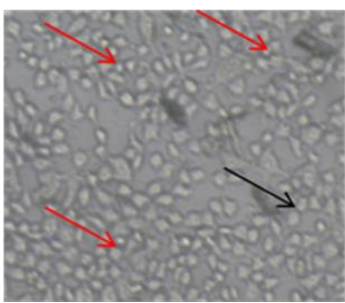

$100 \mu \mathrm{L}$

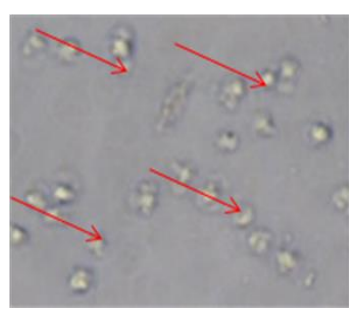

$150 \mu \mathrm{L}$

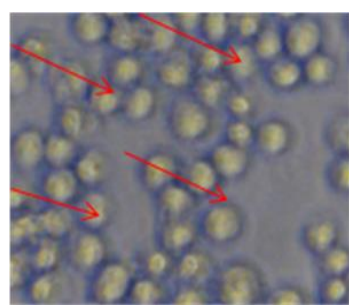

$30 \mu \mathrm{L}$

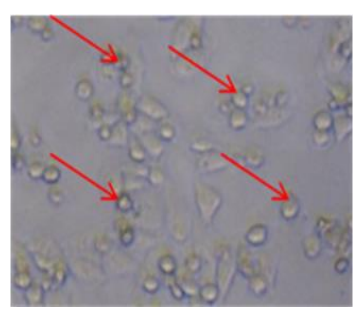

$400 \mu \mathrm{L}$

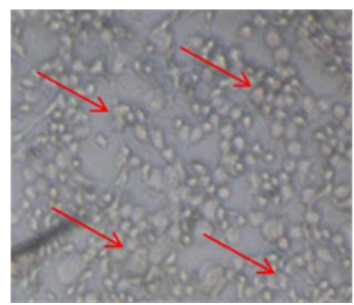

$200 \mu \mathrm{L}$

Figure 2. Morphological changing caused by SEE treatment comparing to control cell. (a) T47D cancer cells (b)WiDr cancer cells; (c) HeLa cancer cells; (d) Vero normal cells. Morphological changing representing cells' dead show by red arrow. Cell morphology was examined by using inverted microscope with magnification $400 x$ 
Table I. IC 50 and SI value

\begin{tabular}{ccc}
\hline Cells & $\mathbf{I C}_{\mathbf{5 0}}(\boldsymbol{\mu \mathbf { g } / \mathbf { m l } )}$ & SI \\
\hline T47D & 36 & 3.72 \\
WiDr & 30 & 4.47 \\
HeLa & 327 & 0.41 \\
Vero & 134 & - \\
\hline
\end{tabular}

SEE showed moderate to high cytotoxicity on T47D, WiDr, and HeLa cells with $\mathrm{IC}_{50}$ value $36 \mu \mathrm{g} / \mathrm{mL}, 30 \mu \mathrm{g} / \mathrm{mL}$, and 327 $\mu \mathrm{g} / \mathrm{mL}$, respectively (Table 1 ). The highest potency was showed on WiDr cells. While the lowest $\mathrm{IC}_{50}$ value of SEE was $134 \mu \mathrm{g} / \mathrm{mL}$ on Vero cells, as we expected. In order to evaluate the selectivity of SEE, we calculated the selectivity index (SI) value of SEE on cancer cells. SI value was calculated using a formula based on previous study (Prayong, et al., 2008), by comparing the $\mathrm{IC}_{50}$ value of $\mathrm{SEE}$ on Vero normal cells to $\mathrm{IC}_{50}$ value on cancer cells (Table 1). SEE showed selective cytotoxicity on T47D and WiDr with SI value more than 3. On the other hand, SEE did not selective on HeLa cells with SI less than 3.

\section{DISCUSSION}

In this study, we observe the cytotoxic properties of secang's heartwood ethanolic extract (SEE) and its selectivity directed T47D breast cancer cells, WiDr colon cancer cells and HeLa cervical cancer cells. Development of molecularly targeted agent that more specific kills cancer cells and have less damage to normal cells is still the main goal in anticancer drug discovery (Nurulita, et al., 2011). Many researchers are now interested in examining the use of herbal medicines as a health care method.

SEE showed moderate to high potency as chemopreventive agent based on its cytotoxic effect on T47D, WiDr, and HeLa cells. Since SEE had high potency of cytotoxicity, it is important to reveal the selectivity of the extract. SEE showed moderate cytotoxicity on Vero cells. To determine the SEE selectivity, SI was calculated. SEE showed selective cytotoxic activity on T47D and WiDr cells (SI>3), but not selective on HeLa cells $(\mathrm{SI}<3)$.

The differences activity of SEE on several cells might caused by differences in cells characteristic or difference target of action. T47D cells have a mutation of p53 and express estrogen receptor (ER) (Schafer, et al.,
2000). Compounds isolated from methanolic extract of $C$. sappan exhibited partial antiestrogenic activity on MCF-7 cells (Lai, et al., 2011). Upregulation of $\mathrm{p} 21$ might occurred through p53 independent pathway leading to inhibition of cell cycle (Kim, et al., 2012). Extract of $C$. sappan also showed anticancer activity on HNSCC4 and HNSCC31 cells (head and neck cancer cells) upregulation of p21WAF1/CIP1 (Kim, et al., 2005). SEE proposed to inhibit T47D cell viability through antiestrogenic activity, and inhibition cell cycle, but the mechanism need to be explored further.

WiDr cells show overexpression of COX-2 and mutant of p53 (Palozza, et al., 2005; Bijman, et al., 2008). Apoptosis occured through p53 independent pathways, including activation of p73 (Levrero, et al., 2000). Ethanolic extract of $C$. sappan reduced levels of inflammatory cytokine and expression of COX2 and transcription factor of NF- $\kappa$ B p65 in paw cartilage of CIA rats (Wang, et al., 2011). Brazilin inhibits cell cycle through activation p21 and p27 on U266 cells (Kim, et al., 2012). Sappanchalcone, a flavonoid isolated from $C$. sappan, induces apoptosis through inhibition of p38, ERK, JNK, and NF- $\mathrm{B}$ signaling on oral cancer cells (Lee, et al., 2011). SEE proposed to reduce $\mathrm{WiDr}$ cell viability through downregulation of $\mathrm{COX}-2$ and $\mathrm{NF}-\kappa \mathrm{B}$, but the mechanism need to be clarified more details.

HeLa cells have HPV 18 sequences that express E6 and E7 causing p53 degradation (Goodwin and DiMaio, 2000). Zheng, et al. (2006) reported that the induction of apoptosis on HeLa cells is mediated by upregulation Bax and downregulation of bcl-2. SEE showed moderate cytotoxicity on HeLa cells. Compounds of SEE might be selectively effective on receptor on T47D and WiDr cells rather than receptor on HeLa cells. Binding of FasL in Fas receptor is responsible for p53 independent apoptosis (Reuter, et al., 2008). HeLa cells induce FasL expression via Corticotropin-releasing hormone (CRH) (Taliouri, et al., 2012). Higher-affinity antibodies (FasL) performed a significant 
decrease, rather than an increase, in agonist activity at the Fas receptor (Chodorge, et al., 2012). Compounds in SEE might be influence affinity of FasL and Fas receptor, but the mechanism must be explored in the next study.

Extract of heartwood of secang also safe to be consumed. Secang has been used as ingredients of traditional beverage in Central Java, Indonesia. The extract of $C$. sappan wood showed neither toxicity in terms of general behavior change, mortality, change in gross appearance of internal organs nor produce any acute and subacute toxicity in both female and male rats (Sireeratawong, et al., 2010). In vivo study of ethanol extract of C.sappan L on mice fed a high-cholesterol diet showed increase of hepatic antioxidative indicators, as well as decrease of intracellular ROS, LOX-1, and nuclear translocation of $\mathrm{NF \kappa B}$ on in vitro study in cultured human umbilical vein endothelial cells (HUVECs) (Lee et al., 2010). The results of this present study, adds the scientific evidence of $C$. sappan considering its potency as a cancer chemopreventive agent.

\section{CONCLUSION}

Heartwood of secang ethanolic extract (SEE) possesses selectivity effect on T47D and WiDr cancer cells but not on HeLa cancer cells. Further Caesalpinia sappan reveals prospective properties to be developed as cancer chemopreventive agent.

\section{ACKNOWLEDGEMENT}

The authors thank DP2M DIKTI for funding this research by Program Kreativitas Mahasiswa Penelitian (PKMP) 2012, and Prof. Dr. Edy Meiyanto, M.Si., Apt. for reviewing this manuscript.

\section{REFERENCES}

Bijman, Bijman, M.N., Hermelink, C.A., van Berkel, M.P., Laan, A.C., Janmaat, M.L., Peters, G.J., et al., 2008, Interaction between Celecoxib and Docetaxel or Cisplatin in Human Cell Lines of Ovarian Cancer and Colon Cancer is Independent of COX-2 Expression Levels, Biochem. Pharmacol., 75(2), 427437.

Bock, C. and Lengauer, T., 2012, Managing Drug Resistance in Cancer: Lessons from HIV Therapy, Nat. Rev. Cancer, I2(7), 494-50।.

Bowles, E.J, Wellman, R., Feigelson, H.S., Onitilo, A.A., Freedman, A.N., Delate, T., et al., 2012, Risk of Heart Failure in Breast Cancer Patients After Anthracycline and Trastuzumab Treatment: A Retrospective Cohort Study, J. Natl. Cancer Inst., I 04(17), 1293-1305.

Chodorge, M., Züger, S., Stirnimann, C., Briand, C., Jermutus, L., Grütter, M.G., et al, 2012, A series of Fas Receptor Agonist Antibodies that Demonstrate An Inverse Correlation between Affinity and Potency, Cell Death Differ., 19(7), I I87-II 95.

Goodwin, E.C. and DiMaio, D., 2000, Repression of Human Papillomavirus Oncogenes in Hela Cervical Carcinoma Cells Causes the Orderly Reactivation of Dormant Tumor Suppressor Pathways, Proc. Natl. Acad. Sci. USA, 97(23), I25I3-125I8.

Han, X., Pan, J., Ren, D., Cheng, Y., Fan, P. and Lou, H., 2008, Naringenin-7-Oglucoside Protects Against Doxorubicin-induced Toxicity in H9c2 Cardiomyocytes by Induction of Endogenous Antioxidant Enzymes, Food Chem. Toxicol., 46(9), 3|40-3। 46.

Kim, B., Kim, S.H., Jeong, S.J., Sohn, E.J., Jung, J.H., Lee, M.H., et al., 2012, Brazilin Induces Apoptosis and G2/M Arrest via Inactivation of Histone Deacetylase in Multiple Myeloma U266 Cells, J. Agric. Food Chem., 60(39), 9882-9889.

Kim, E.C., Hwang, Y.S., Lee, H.J., Lee, S.K., Park, M.H., Jeon, B.H., et al., 2005, Caesalpinia sappan Induces Cell Death by Increasing the Expression of p53 and P2IWAFI/CIPI in Head and Neck Cancer Cells, Am. J. Chin. Med., 33(3), 405-4I4.

Lai, W.C., Wang, H.C., Chen, G.Y., Yang, J.C., Korinek, M., Hsieh, C.J., et al., 20II, Using the pER8:GUS Reporter System to Screen for Phytoestrogens from Caesalpinia sappan, J. Nat. Prod., 74(8), 1698-1706.

Lee, M.J, Lee, H.S., Jung, H.J., Lee, C.S., Kim, J.E., Moon, H.I., et al., 2010, Caesalpinia sappan L. ameliorates Hypercholesterolemia in C57BL/6 Mice and Suppresses Inflammatory 
Responses in Human Umbilical Vein Endothelial Cells (HUVECs) by Antioxidant Mechanism, Immunopharmacol. Immunotoxicol., 32(4), 67I-679.

Lee, M.J., Lee, H.S., Kim, H., Yi, H.S., Park, S.D., Moon, H.l., et al, 20l0, Antioxidant Properties of Benzylchroman Derivatives from Caesalpinia sappan L. Against Oxidative Stress Evaluated in vitro, J. Enzyme Inhib. Med. Chem., 25(5), 608-6I4.

Lee, Y.M., Kim, Y.C., Choi, B.J., Lee, D.W., Yoon, J.H. and Kim, E.C., 20II, Mechanism of Sappanchalcone-induced Growth Inhibition and Apoptosis in Human Oral Cancer Cells, Toxicol. In Vitro, 25(8), I782-1788.

Lee, Y.R., Noh, E.M., Han, J.H., Kim, J.M., Hwang, J.K., Hwang, B.M., et al., 2012, Brazilin Inhibits UVB-induced MMP-I/3 Expressions and Secretions by Suppressing the NF-KB Pathway in Human Dermal Fibroblasts, Eur. J. Pharmacol., 674(2-3), 80-86.

Levrero, M., De Laurenzi, V., Constanzo, A., Sabatini, S., Gong, J., Wang, J.Y.J., et al., 2000, The p53/p63/p73 Family of Transcription Factors: Overlapping and Distinct Functions, J. Cell Sci., II3(I0), I66I-I670.

Meyerhardt, J.A. and Mayer, R.J., 2005, Systemic Therapy for Colorectal Cancer, N. Engl. J. Med., 352(5), 476487.

Mosmann T., 1983, Rapid Colorimetric Assay for Cellular Growth and Survival: Aplication to Proliferation and Citotoxicity Assays, J. Immunol. Methods, 65(I-2), 55-63.

Nobili, S., Lippi, D. and Witort, E., 2009, Natural Compounds for Cancer Treatment and Prevention, Pharmacol. Res., 59(6), 365-378.

Nurulita, N., Meiyanto, E., Sugiyanto, 20II, Selectivity of Ethyl Acetate Fraction of Gynura Procumbens on Colon Cancer and Breast Cancer, Indones. J. Cancer Chemoprevent., 2(3), 274-280.

Palozza, P., Serini, S., Maggiano, N., Giuseppe, T., Navarra, P. and Ranelletti, F.O., 2005, $\beta$-Carotene Downregulates the Steady-state and Heregulin-a-Induced COX-2 Pathways in Colon Cancer Cells, J. Nutr., I35(I), I29-I36.
Park, K.J., Yang, S.H. and Eun, Y.A., 2002, Cytotoxic Effects of Korean Medicinal Herbs Determined with Hepatocellular Carcinoma Cell Lines, Pharm. Biol., 40(3), 189-195.

Prayong, P., Barusrux, S. and Weerapreeyakul, N., 2008, Cytotoxic Activity Screening of Some Indigenous Thai Plants, Fitoterapia, 79(7-8), 598-60I.

Reuter, S., Eifes, S., Dicato, M., Aggarwal, B.B. and Diederich, M., 2008, Modulation of Anti-apoptotic and Survival Pathways by Curcumin as A Strategy to Induce Apoptosis in Cancer Cells, Biochem. Pharmacol., 76(II), |340-135I.

Safitri, R., Tarigan, P., Freisleben, H.J., Rumampuk, R.J. and Murakami, A., 2003. Antioxidant Activity in vitro of Two Aromatic Compounds from Caesalpinia sappan L., Biofactors, I9(I2), $7 \mathrm{I}-77$.

Schafer, J.M., Lee, E.S., O’Regan, R.M., Yao, K., Jordan, V.C., 2000, Rapid Development of Tamoxifen-stimulated Mutant p53 Breast Tumors (T47D) in Athymic Mice, Clin. Cancer Res., 6(II), 4373-4380.

Sireeratawong, S., Piyabhan, P., Singhalak, T., Wongkrajang, Y., Temsiririrkkul, R., Punsrirat, J., et al., 2010, Toxicity Evaluation of Sappan wood Extract in Rats, J. Med. Assoc. Thai, 93(Suppl 7), S50-S57.

Staerk, D., Lykkeberg, A.K., Christensen, J., Budnik, B.A., Abe, F. and Jaroszewski, J.W., 2002, In vitro Cytotoxic Activity of Phenanthroindolizidine Alkaloids from Cynanchum vincetoxicum and Tylophora tanakae Against DrugSensitive and Multidrug Resistant Cancer Cells, J. Nat. Prod., 65(9), I2991302.

Taliouri, E., Vrekoussis, T., Vergetaki, A., Agorastos, T. and Makrigiannakis, A., 2012, Corticotropin-releasing Hormone (CRH) is Expressed in the Human Cervical Carcinoma Cells (HeLa) and Upregulates the Expression of Fas Ligand, Tumour Biol., 34(I), I25-130.

Wang, Y.Z., Sun, S.Q. and Zhou, Y.B., 20II, Extract of the Dried Heartwood of Caesalpinia sappan L. Attenuates Collagen-induced Arthritis, J. Ethnopharmacol., I36(I), 27I-278. 
Wicaksono, D., Arung, E.T., Sandra, F., 2008, Aktivitas Antikanker dari Kayu Secang, Cermin Dunia Kedokteran, 35(3), I33137.

Wu, J., Zhang, M., Jia, H., Huang, X., Zhang, Q., Hou, J., et al, 20l0, Protosappanin A Induces immunosuppression of Rats Heart Transplantation Targeting $T$ Cells in Grafts via NF-kappaB Pathway, Naunyn Schmiedebergs Arch. Pharmacol., 38I(I), 83-92.
Yen, C., Goto, K.N., Hwang, T.L., Wu, P.C., Natschke, S.L.M., Lai, W.C., et al, 20I0, Total Synthesis and Evaluation of Brazilein and Analogs as Antiinflammatory and Cytotoxic Agents, Bioorg. Med. Chem. Lett., 20(3), I0371039.

Zheng, Q.F., Sun, H.X., He, Q.J. and Ye, Y.P., 2006, Induction of Apoptosis in HeLa Cells by $3 \beta$-Hydroxyurs-12-en-27-oic Acid, Chem. Biodivers., 3(7), 742-753. 